\title{
Adolescentes gays, lésbicas e bissexuais: cuidado para aumentar a auto-estima dessa população oprimida
}

\author{
Maria Regina Domingues de Azevedo* \\ André Cavanha Babichaki**
}

Em artigo publicado na revista "The Nurse Practitioner", vol. 22, de Fevereiro de 1997, Nelson discute as dificuldades encontradas pelos adolescentes gays na nossa sociedade, que acabam culminando com altos índices de morbi-mortalidade dessa população. Apresenta os principais fatores decorrentes dessa discriminação e sugere algumas estratégias de como os profissionais de saúde podem ajudar esses adolescentes, estreitando a relação entre estes e a sociedade.

No início do trabalho, o autor refere que 5 a $10 \%$ da população adolescente apresenta tendência homo ou bissexual.

Nelson coloca que a identidade sexual do adolescente será determinada por fatores externos e internos, passando por vários estágios, que são: 1- sensibilização e conhecimento, 2- confusão de identidade e reconhecimento, 3- assumir a identidade e aceitação, 4- compromisso e afirmação.

\footnotetext{
* Psicóloga; Docente da Disciplina de Pediatria e Puericultura da FMFUABC.

***Doutorando da FMFUABC.

Recebido em 13.04.98

Aprovado em 20.04.98
} 
Para os adolescentes gays, essa noção de diferença em relação aos garotos da mesma idade começa na escola, mas apesar de já sentirem atração pelo mesmo sexo, ainda não se identificam como sendo homossexuais.

O autor relata que os adolescentes homossexuais masculinos, tem iniciação sexual 5 a 7 anos mais tarde que os heterossexuais.

Já na puberdade, esses jovens começam a se identificar como homo ou bissexuais, gerando conflitos e ansiedade. A sociedade passa a imagem de que só as pessoas heterossexuais são saudáveis, contribuindo assim para o isolamento, negação e auto-destruição desses adolescentes.

O principal fator citado para aceitação de sua identidade sexual é conhecendo comunidades gays, onde as igualdades aparecem, facilitando o processo de auto-conhecimento e auto-definição. É difícil decidir o momento certo para revelar-se frente à sociedade, portanto o jovem homossexual não deve ser forçado a tal decisão.

Nos Estados Unidos, o suicídio é a maior causa de mortalidade entre adolescentes gays, sendo que $42 \%$ apresenta história de tentativa de suicídio e $30 \%$ se suicidam. O autor coloca que isso acontece principalmente com aqueles que buscam assumir sua posição muito cedo, e decorre de pouco suporte intra e extra familiar, baixa auto-estima e falta de aceitação de si próprios.

A AIDS é apresentada como a sexta causa de morte entre os jovens de 15 a 24 anos nos Estados Unidos.

Os maiores responsáveis pela transmissão do vírus da AIDS são os homossexuais adultos, que iniciam sexualmente esses adolescentes nas comunidades gays.

Segundo o autor, um terço dos garotos gays relatam prática de sexo anal sem proteção, devido ao uso de drogas, por opção consciente e outras vezes, por serem vítimas de abuso sexual.

As jovens lésbicas ou bissexuais também são consideradas grupo de risco, pois contam com experiências heterossexuais.

A violência é a maior causa de morbi-mortalidade no universo adolescente. Sendo o homo ou bissexuais. Devido ao estigma social que sofre a população gay, além da baixa auto-estima e isolamento, desenvolvem um alto grau de depressão e de ansiedade.

O fato de sentirem-se forçados a sair de casa, pela não aceitação da família de sua vida sexual, leva-os a encontrar na prostituição um modo de sobrevivência.

A escola também dificulta a vida desses jovens, com seus preconceitos e rigidez. 
Algumas instituições religiosas não permitem a participação de homo ou bissexuais em suas atividades.

O sistema de saúde também é colocado por Nelson como responsável por esta situação. Os profissionais muitas vezes demonstram hostilidade e frieza frente a estes pacientes.

Considerando as questões levantadas, podemos afirmar que existe uma necessidade urgente por parte dos profissionais das áreas de saúde e educação na aquisição de maior e melhor conhecimento no que se refere ao processo de desenvolvimento da sexualidade. Faz-se necessário também adequação da linguagem, respeito e atitude de neutralidade (sem preconceitos e sem julgamento) no trato e no convívio com esses jovens.

Os adolescentes homo ou bissexuais enfrentam as mesmas dificuldades que os demais adolescentes, porém precisam lutar muito mais (interna e externamente), para se auto-aceitarem e se sentirem aceitos.

A sociedade pode facilitar esse processo, buscando conhecer melhor essa população e procurando entender como vivem e como se sentem esses adolescentes. Afinal, o que todo jovem deseja é apenas ser feliz. 